\title{
THE ESSENTIAL FACILITIES DOCTRINE: THE LOST MESSAge OF TERMinAL RAILROAD *
}

\section{Stephen M. Maurer and Suzanne Scotchmer University of California, Berkeley}

\begin{abstract}
The growing importance of shared networks, shared platforms and shared standards leads to a renewed discussion of the essential facilities doctrine of antitrust. This is an area where European law and American law have diverged. In Trinko (2007), the U.S. Supreme Court came close to abolishing it. At the same time, it was reinvigorated by the European Commission, which asserted it successfully in E.C. v. Microsoft, and then, facing criticism, clarified the doctrine in a Guidance document.

We harmonize the main cases around the doctrine's original but often forgotten purpose namely, harvesting economic synergies through sharing. We argue that, absent such a doctrine, these synergies could be lost as firms either avoid sharing to avoid antitrust liability, or create sharing arrangements that undermine competition. We show how and why the original purpose of the doctrine has become entangled with other antitrust issues, in particular, leveraging. We systematize the sharing rules that have been imposed or allowed, with an emphasis on how to harvest synergies while mitigating any harm to competition.
\end{abstract}

\section{Contents}

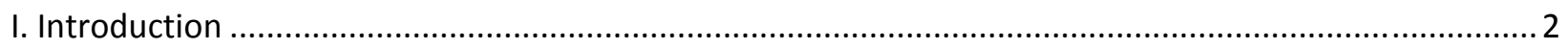

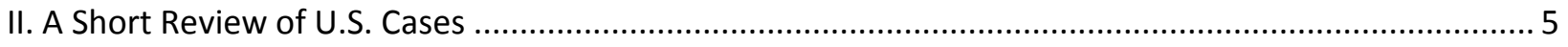

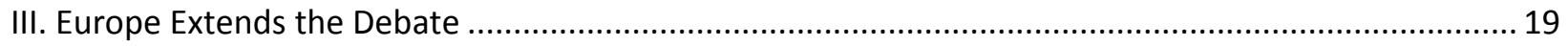

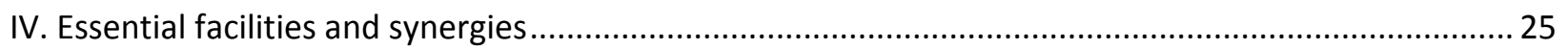

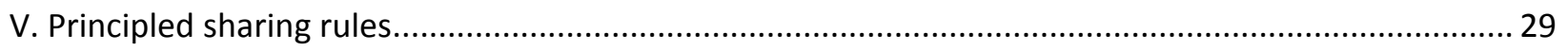

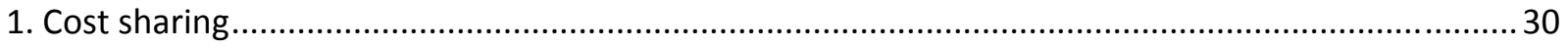

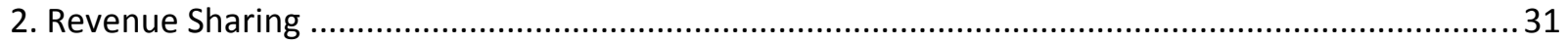

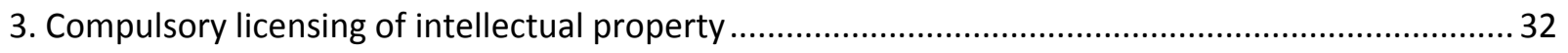

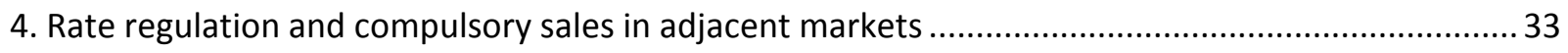

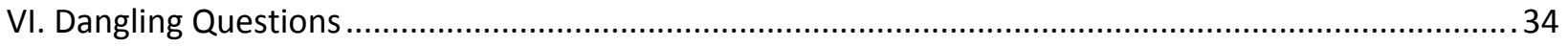

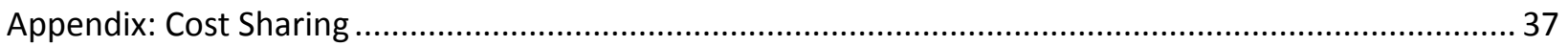

\footnotetext{
${ }^{*}$ We thank the Sloan Foundation and the Toulouse Network for Information Technology for financial support, and the Touloluse School of Economics for generous hospitality during the preparation of this paper. We thank Jacques Cremer, Einer Elhauge, Harry Furst, Paul Seabright, Jean Tirole and the seminar participants at the Toulouse School of Economics, the Microsoft antitrust group, Berkeley Law, The University of Texas (Austin) Law School, and Yale Law School for helpful comments.
} 


\section{Introduction ${ }^{1}$}

The essential facilities doctrine is famously disreputable. Many scholars make no bones about wanting to abolish it. ${ }^{2}$ In the meantime, they seek to restrict it with a forest of "limiting principles." ${ }^{3}$ More fundamentally, they deny that it is a theory at all but an "epithet" "catchphrase" for fact patterns whose "contours" are "unclear." 5 Indeed, even its friends concede that it is "undertheorized," "unarticulated," " or no more than a "useful label."7 Since the 1990s this judgment has become self-fulfilling. Instead of trying to clarify the doctrine, today's $\operatorname{trial}^{8}$ and appellate 9 judges go out of their way to decide cases on other grounds. In 2004, the

\footnotetext{
${ }^{1}$ Prof. Scotchmer passed away following a brief illness in January 2014. The current text is presented as she left it for the last time on October 20, 2013. Obvious typographical and citation errors have been corrected in the interests of readability. - smm.

${ }^{2}$ Herbert Hovenkamp, Federal Antitrust Policy: The Law of Competition and Its Practice (West 2011) at 336 ("The so-called 'essential facility' doctrine is one of the most troublesome, incoherent, and unmanageable bases for Sherman $\S 2$ liability. The antitrust world would almost certainly be a better place if it were jettisoned, with a little fine tuning of the general doctrine of refusal to deal to fill any gaps.”)

${ }^{3}$ Herbert Hovenkamp, Federal Antitrust Policy: The Law of Competition and its Practice IIIB (2d ed. 1999) at 196-97 ("we take the more constrained route of seeking to limit the doctrine's scope so as to make it as consistent as possible with the general goals of antitrust, which are to permit firms to enter and operate in markets.”)

${ }^{4}$ Philip J. Areeda, “Essential Facilities: An Epithet in Need of Limiting Principles,” 58 Antitrust L.J. 841 (1989); Herbert Hovenkamp, Federal Antitrust Policy: The Law of Competition and its Practice IIIB at 196 (2d ed. 1999) at 199 (“The 'essential facility' is just an epithet describing the monopolist's situation: the monopolist possesses something that the plaintiff wants. It is not an independent tool of analysis; it is only a label - a label that beguiles some commentators and courts into pronouncing a duty to deal without analyzing the implications already considered at length in this chapter.”)

${ }^{5}$ Sergio Baches Opi, “The Application of the Essential Facilities Doctrine to Intellectual Property Licensing in the European Union and the United States: Are Intellectual Property Rights Still Sacrosanct?” 11 Fordham Intell. Prop. L.J. 409-507 (2001) at 419-20.

${ }^{6}$ Marina Lao, “Networks, Access, and Essential Facilities: From Terminal Railroad to Microsoft,” 62 S.M.U. L. Rev. 557-595 (2009), at 558.

${ }^{7}$ Opi supra at $419-20$.

${ }^{8}$ Spencer Weber Waller, “Areeda, Epithets, and Essential Facilities,” 2008 Wis. L. Rev. 359-386 (2008), at 363.

${ }^{9}$ Waller, supra, at 369-370 (noting that appeals courts "almost always” affirm lower court decisions on different grounds so that the doctrine becomes a "make-weight.”)
} 
Supreme Court's Trinko ${ }^{10}$ opinion strongly hinted that the doctrine had at the very least reached its “outer limits” and might not exist at all. ${ }^{11}$

These reactions are understandable. First, it is an antitrust doctrine that demands cooperation among rivals. This seems at odds with Section 1 of the Sherman Act, in which many forms of "cooperation" are condemned. Instead of being suspicious of cooperation, the essential facilities doctrine demands it. How can these two bodies of law coexist? Second, many of the cases are brought and decided under Section 2 as refusal-to-deal cases, which has led scholars to ask whether an additional doctrine is necessary. ${ }^{12}$

Third, the doctrine's core cases span a bewildering array of facts and legal contexts. Some involve cooperative associations that span hundreds of parties; others just two. Some talk narrowly of feasible relief; others of a duty to share. It is tempting to avoid this chaos by getting rid of the doctrine entirely.

Reforms since the 1970s have almost always proceeded as negative definitions, that is, defining what the doctrine is not. Initially, these refinements took the form of new proof requirements or “elements.” They accelerated after Prof. Areeda’s celebrated call for "limiting principles” in 1989. New refinements continue to appear in court cases and influential treatises.

The negative definitions have been wildly successful in choking off litigation. However, they do almost nothing to explain why a duty to share should exist or when to enforce it. This article breaks with recent tradition by trying to formulate a coherent doctrine rooted in the cases, and exploring the consequences of this doctrine for competition and consumer welfare.

We argue that most of the principal cases follow an important common thread that is beautifully anticipated in Terminal Railroad ${ }^{13}$ even though the doctrine has wandered in other directions. The lost message is that antitrust interventions must not discard beneficial synergies that require sharing. This common thread goes a long distance to unifying the cases on both sides of the Atlantic. We anticipate that the doctrine will gain renewed importance, since the digital economy is a new source of synergies. For example, there is a natural synergy in aggregating information

\footnotetext{
${ }^{10}$ Verizon Comms., Inc. v. Law Offices of Curtis V. Trinko, 540 U.S. 398 (2004).

${ }^{11}$ But see Christina Bohannan and Herbert Hovenkamp, Creation Without Restraint: Promoting Liberty and Rivalry in Innovation (Oxford 2012) at 316 (saying that Trinko can be read narrowly so that it is limited to the proposition that antitrust law should not be used as an "overlay" to compel sharing when "regulators are already managing, and apparently quite well.”)

${ }^{12}$ See, for example, Herbert Hovenkamp, Federal Antitrust Policy: The Law of Competition and its Practice IIIB (2d ed. 1999) , §7.7, at 305.

${ }^{13}$ Terminal Railroad Co. v. US, 224 US 383 (1912).
} 
among firms that collect it, such as internet search firms, advertising platforms, and online vendors. ${ }^{14}$ Economic evidence of these synergies is already emerging. ${ }^{15}$

The problem, as the Trinko court reminds us, is that sharing must be principled. One hundred years ago, Terminal Railroad claimed that in at least some cases, judges can implement sharing rules that simultaneously protect competition and preserve synergies. In what follows, we investigate how well this promise has been realized, and reformulate the doctrine in line with its original purpose.

We are motivated in large part by observing that with respect to the essential facilities doctrine, American and European competition laws are diverging. The Supreme Court discredited the doctrine in the U.S. by refusing to assert it in Trinko (2004), and by loudly noting that the Court had never acknowledged such a doctrine. However, a few years later the European Commission gave it new life by asserting it successfully in E.C. v. Microsoft (2008). ${ }^{16}$ Because Microsoft (2008) was criticized as unprincipled, the European Commission then published a Guidance to explain how they will enforce the doctrine. ${ }^{17}$ That breathed even more life into it.

The heart of the essential facilities doctrine is that sharing may create synergies that either enhance consumer value or reduce costs, and therefore help consumers. But when, exactly, do such synergies exist? How can they be harvested without damaging competition so badly that consumers are worse off than without sharing?

${ }^{14}$ See Herbert Hovenkamp, Federal Antitrust Policy: The Law of Competition and its Practice IIIB (2d ed. 1999) at 309 (stressing that networks cannot exist without "a great deal of cooperation” between rival firms ) and Christina Bohannan and Herbert Hovenkamp, Creation Without Restraint: Promoting Liberty and Rivalry in Innovation (Oxford 2012) at 306 ("cooperation is necessary for the network's continued efficient operation”). Also Herbert Hovenkamp, Federal Antitrust Policy: The Law of Competition and Its Practice (West 2011) at 340 ("Applying the term 'essential facility' to such networks is not essential to the theory, but it is not inappropriate either.”).

${ }^{15}$ See, for example, Erik Brynjolfsson, Michael D. Smith, and Yu (Jeffrey) Hu, "Consumer Surplus in the Digital Economy: Estimating the Value of Increased Product Variety at Online Bookstores", Management Science 49(11), November 2003, at p. 1580 ("Our analysis indicates that increased product variety of online bookstores enhanced consumer welfare by $\$ 731$ million to $\$ 1.03$ billion in the year 2000, which is at least five times as large as the consumer welfare gain from increased competition and lower prices in the market.")

${ }^{16}$ Case COMP/C-3/37.792, EC Commission v. Microsoft.

${ }^{17}$ Guidance on the Commission's enforcement priorities in applying Article 82 of the EC Treaty to abusive exclusionary conduct by dominant undertakings, Official Journal C 045, 24/02/2009 P. 0007 0020 . 
We proceed as follows. Section II reviews the best-known essential facilities decisions, stressing the practical judgments that led judges to conclude that sharing would produce net synergies and, inferentially, was being resisted for improper reasons. Section III reviews European Community law emphasizing how recent decisions have reinvigorated the doctrine, particularly in intellectual property cases. Section IV proposes elements of a rationalized doctrine. Section V categorizes the cases according to the sharing rules that were imposed, and explains their competitive effects. Section VI addresses some questions that critics are sure to raise.

\section{A Short Review of U.S. Cases}

In this section we remind readers of the salient features of the key cases, especially the sometimes forgotten synergies that make sharing attractive, as well as other reasons that courts have ordered sharing.

We use these cases to stress two important problems that courts either did or should have addressed when trying to harvest synergies. First, sharing should be structured in a way that limits the exercise of market power. Second, assuming that the price is controlled, sharing should be nondiscriminatory. This maximizes the value of synergies, at least in most cases, and also ensures that power over the shared facility cannot be leveraged into an adjacent market.

Terminal Railroad marked the first bold attempt to find sharing rules that achieve the synergies of joint operations while avoiding cartelization. The problem concerned relatively simple assets, two bridges and a ferry, for which the capacity needed to be managed jointly for the benefit of all the railroads. Successive cases over the $20^{\text {th }}$ Century considered different kinds of synergies, and gradually extended sharing rules to complex businesses (newspaper advertising, ski slopes), regulated utilities (telephones, power lines), and intellectual property. The bridges and ferry in Terminal Railroad had been operated separately prior to the merger that resulted in litigation. However, as the century progressed, compelled sharing was extended to assets that had never been owned separately. In this section we detail the economic logic that led judges to accept and eventually become disillusioned with these successive expansions.

In Terminal Railroad, a St. Louis railroad cartel had acquired the two bridges and ferry, which were the only facilities for transporting railroad trains across the Mississippi river. ${ }^{18}$ While it was physically possible to build a fourth facility, the cost to any one company would have been

${ }^{18}$ Id. at 391 - 92, 396. 
"prohibitive." ${ }^{19}$ The Court found that the arrangement violated both Section 1 and Section 2 of the Sherman Act. ${ }^{20}$

Given that the Court had decided the Standard Oil case the previous year, the remedy should have been obvious: divestiture. ${ }^{21}$ Divestiture would have restored the status quo ante, in which all three facilities had operated independently. ${ }^{22}$ Despite this, the Court hesitated. Relying on Albert Perkins, a government-appointed railroad expert, it explained that "the terminals of Railroad lines in any large city should be unified as far as possible, and that such unification may be of the greatest public utility and of immeasurable advantage to commerce, state and interstate.” These synergies would necessarily be lost if the facilities were operated independently. ${ }^{23}$ The Court was seemingly faced with a cruel choice: Leave defendants' market power intact or sacrifice important synergies. Either would make society poorer.

But Perkins asserted a beguiling way out: Open the facility to all railroads on the condition "that every railroad using the service should be a joint owner and equally interested in the control and management. This, he thinks, will serve the greatest possible economy, and will give the most efficient service without discrimination. ${ }^{24}$ According to Perkins, "the facilities would belong to each relatively to its own business" so that "The charge for the haul thus lengthened would then be properly absorbed by the through rate, leaving nothing to be added to that to be charged the shipper or consignee but switching and storage charges proper."25

${ }^{19}$ Id. at 397.

${ }^{20}$ Id. at 392 ("When a combination prohibits "any other reasonable means” of entering the market both Section 1 and Section 2 are violated.”)

${ }^{21}$ Standard Oil Co. of New Jersey v. United States, 221 U.S. 1 (1911).

${ }^{22}$ Id. at 391, 399.

${ }^{23}$ Id. at 405. See also id. at 409 ("If, as we have already said, the combination of two or more mere terminal companies into a single system does not violate the prohibition of the statute against contracts and combinations in restraint of interstate commerce, it is because such a combination may be of the greatest public utility."). The Court noted that separate ownership of facilities had promoted competition but also resulted "in some cases in an unnecessary duplication of facilities." Id. at 393.

${ }^{24}$ Id. at 406. Seven decades later, Prof. Areeda endorsed Perkins’ argument by remarking that the "Supreme Court wisely concluded that the most efficient remedy was to admit nonmember companies to the consortium."

${ }^{25} I d$. at 406. 
Whatever defendants may actually have thought, they found it hard to disagree. On the one hand, they already practiced such an arrangement among themselves. ${ }^{26}$ On the other, they had told the Court that they were prepared to open the facility "upon paying the same charges paid by the proprietary companies. ${ }^{, 27}$ Ordering them to share would take them at their word. ${ }^{28}$ Furthermore, the Court would not insist: If the parties failed to come to an acceptable agreement, the court would simply follow Standard Oil by ordering "complete disjoinder of the three systems."29

Was the Court right to believe Perkins when he said that his remedy was "equally adequate" to divestiture? ${ }^{30}$ The key condition seemed to be that access prices would "produce no more revenue than shall equal the [facility's] fixed charges, operating and maintenance expenses." ${ }^{\text {"31 }}$ This condition was enforced by the fact that "No dividends have ever been paid, and the company disclaims any purpose to pay dividends. ${ }^{, 32}$ Apparently the facility would operate as a nonprofit company.

Unfortunately, the Court said little about why, or in what sense, the conditions they accepted would lead to competitive pricing. The parties were ordered to amend the facility's charter so that new railroads could become members "upon such just and reasonable terms as shall place such applying company upon a plane of equality in respect of benefits and burdens with the present proprietary companies." Alternatively, railroads that did not wish to become owners would be allowed to use the facility "upon such just and reasonable terms and regulations as will, in respect of use, character and cost of service, place every such company upon as nearly an equal plane as may be with respect to expenses and charges as that occupied by the proprietary companies." ${ }^{\text {"33 }}$ The Court asserted that this arrangement would be "plainly" lawful because the

\footnotetext{
${ }^{26} I d$. at 400 ("That other companies are permitted to use the facilities of the Terminal Company upon paying the same charges paid by the proprietary companies seems to be conceded.”)

${ }^{27}$ Id .at 400. The Court noted that such openness was not required by the operating company’s charter.

${ }^{28} I d$. at 411 Court ordered the parties to reach an agreement providing for the admission of new owners on "just and reasonable terms" and providing also "definitely for the use of the terminal facilities by any other railroad not electing to become a joint owner."

${ }^{29} I d$. at 412.

${ }^{30}$ Id. at 409 .

${ }^{31} I d$. at 400.

${ }^{32}$ Id. at 401 . The Court worried that this restriction could be evaded, since there appeared to be no formal restriction on paying dividends in the future and/or that the members could realize an "indirect profit through ownership of obligations of the absorbed companies.”

${ }^{33}$ Id. at 411.
} 
facility would be "the impartial agent" and "bona fide agent and servant of every railroad line which shall use its facilities. ${ }^{34}$ The Court stressed the nondiscriminatory aspect of the arrangement, as we explain in Section V. The nonprofit aspect was also key, although the Court did not stress this. Nondiscriminatory prices without the nonprofit condition could be even higher than prices in a market where the firms were competing but not sharing facilities.

Critics of the essential facilities doctrine have worked hard to distinguish Terminal Railroad on the ground that the Court would have reached the same result following an ordinary horizontal monopolies analysis and/or as a novel alternative to divestiture relief. ${ }^{35}$ However, the Court's emphasis on synergies requires a different analysis. Far from condemning sharing, the Court praised it as offering "the greatest public utility." Illegality under "both the first and second sections" of the Sherman Act only entered the picture when the parties attempted to restrict sharing to "less than all of the companies" that needed the facility. ${ }^{36}$ However, as we will spell out in Section V, it is the nonprofit feature that allows sharing without the high prices that a cartel would typically support.

Associated Press was brought under both sections of the Sherman Act, but summary judgment was granted under Section $1 .{ }^{37}$ Similarly to Terminal Railroad, AP members contributed fees ${ }^{38}$ that "contemplate[d] no profit to AP"39 and received AP stories in return. The cost was

\footnotetext{
${ }^{34}$ Id. at $410-411$.

${ }^{35}$ Areeda, supra (arguing “most Supreme Court ... can be explained without reference to it); David Reiffen \& Andrew N. Kleit, Terminal Railroad Revisited: Foreclosure of an Essential Facility or Simple Horizontal Monopoly?” 33 J.L. \& Econ. 419 (1990) (arguing that Terminal Railroad is indistinguishable from an ordinary cartel case).

${ }^{36}$ Id. at 409. The Court added that would-be competitors might normally be required to build their own facility but lacked "reasonable means to do so. Id. This was based on defendants' admission that the unique "geographical and topographical situation" in St. Louis made "the cost to any one company ... prohibitive." Id. at 397.

${ }^{37}$ Justice Douglas noted that an exclusive news sharing arrangement between newspapers potentially violated both Section 1 and Section 2. Id. 24.

${ }^{38}$ Id. at 9. Members also contributed news stories to AP. They were not allowed to sell their news to any other agency or publisher. Id.

${ }^{39}$ Id. at 10. See also United States v. AP, 52 F. Supp. 362 (S.D.N.Y. 1943) (“AP is not a profit-making company, but strictly co-operative, paying its expenses by assessments levied upon its members, and never declaring any dividends, although it has accumulated large assets.”)
} 
distributed among member newspapers in proportion to the populations of the regions they served, regardless of actual circulation. ${ }^{40}$

The synergy in this arrangement was, if anything, even starker than in Terminal Railroad. Each new member shared the costs of newsgathering without degrading the resource. The potential synergies were limitless. It would have been economically efficient for every newspaper in the country, including rivals, to join the AP. In contrast, railroad bridges eventually become congested.

There were also important differences in how the shared facilities were organized. First, the Terminal Railroad incumbents had claimed that their organization was open to all railroads. AP's membership policy depended on who the applicant competed with. Applicants who did not compete with an existing member faced a "very simple and non-burdensome road for admission" which did not require "payment of money or ... any other onerous terms."41 By comparison, applicants who did compete had "a hard road to travel."42 AP had a long history of excluding competing newspapers. This policy had been relaxed by legal challenges, but only slightly. ${ }^{43} \mathrm{By}$ 1945, an applicant who competed with an existing member still had to be approved by a majority vote of all existing members and had to pay AP a sum equal to ten percent of all assessments that

\footnotetext{
${ }^{40}$ The District Court described AP's assessment formula this way: “In levying assessments upon members it divides the United States into areas determined by cities, with a surrounding territory generally of not more than ten miles. The entire levy is allocated 'fundamentally upon a plan of distributing the total cost in proportion to the population served by each member.' Each allotment is then divided among all the members in the same 'field' and city in proportion to their number, not to their circulation. In the course of its existence AP has accumulated tangible property, estimated by it at more than \$7,000,000 - most of which is in the City of New York. In addition, it appraises its 'good-will' and other intangibles at \$12,000,000.” United States v. AP, 52 F. Supp. 362 (S.D.N.Y. 1943). Since 1986 AP has assessed fees based on circulation. Associated Press, "Member Choice Product Guide," at 3. http://www.apexchange.com/BizUI/Front1/docs/MemberChoiceProductGuide.pdf.

${ }^{41}$ Associated Press, supra, at 8.

${ }^{42}$ Id. at 10.

${ }^{43} \mathrm{Id}$. at 10 . AP originally gave existing members an absolute veto power over applications from competing newspapers. This was struck down by the Illinois Supreme Court in 1900. Thereafter, AP was reorganized in New York and adopted new By-Laws which gave members a "right of protest" that could only be overruled by a four-fifths vote of the organization's membership. This rule was watered down following a 1942 investigation by the US Justice Department. However, new entrants still had to (a) pay the Association $10 \%$ of all assessments paid by competing AP members since 1900, (b) relinquish any exclusive rights to any news or news services other than AP, and (c) receive a majority vote of existing members in person or by proxy.
} 
its competitor had paid since $1900 .{ }^{44}$ As Justice Frankfurter noted, "reciprocal self-interest" almost always persuaded a majority to vote no. ${ }^{45}$

In Terminal Railroad, the Court had also been careful to note that forced sharing was only justified where plaintiffs "had no reasonable means" to access other facilities. The AP Court broadened this concept and said that AP could not be duplicated even though partial substitutes were available. ${ }^{46}$ Five Justices affirmed the district court's order holding that AP could no longer consider new applicants' "ability ... to compete with members in the same city and field" in deciding whether to grant admissions. ${ }^{47}$

In Lorain Journal ${ }^{48}$, a dominant newspaper refused to sell ad space to any merchant who also purchased ads from a competing radio station. ${ }^{49}$ This meant that advertisers could buy radio or newspaper ads but not both. The court struck down the practice, arguing that at least "some" businesses considered newspaper advertising "essential for the promotion of...sales in Lorain County" ${ }^{\prime 0}$ and an "indispensable medium of advertising for many Lorain concerns."

The defendant responded " ... that it had a right as a private business concern to select its customers and to refuse to accept advertisements from whomever it pleases." However, the

${ }^{44} I d$. at 11 . The term was said to constitute a "stipulated 'asset value,"” presumably in rough compensation for capital that AP had acquired over the years. Rival services UP and INS required similar compensation to incumbents. Id. at 13-14.

${ }^{45}$ Id.at 27

${ }^{46}$ The record showed that the US hosted "between twenty and thirty" wire services. Furthermore, at least two of these -- U.P.I. and I.N.S. -- were sizable and appeared to conduct a "brisk rivalry" with AP. Id. at 39 (Murphy dissenting). One possible explanation is that AP members paid about $\$ 10,000$ to join AP and received \$13 million worth of news. By comparison, UPI subscribers paid $\$ 6,000$ to receive $\$ 8.6 \mathrm{~m}$ worth of news. Id. at 40. Based on this observation, it is at least possible to argue that U.P.I. was not an acceptable substitute for the larger and more expensive A.P.

${ }^{47} I d$. at 21. However, as Justice Douglas pointed out, this stopped short of deciding whether AP could use non-discriminatory rules to achieve similar ends, most obviously by freezing its membership at current levels. Id. at 24 (Douglas, dissenting). See also Hovenkamp, supra, Vol. IIIB at 202.

${ }^{48}$ Lorain Journal Co. v. United States, 342 US 143 (1951)

${ }^{49}$ Id. at $148-149$.

${ }^{50}$ Id. at 148 .

${ }^{51}$ Id. at 152. 
Court rejected this defense on the ground that "(m)ost rights are qualified" ${ }^{52}$, and "a purposeful means of monopolizing interstate commerce is prohibited by the Sherman Act."53

The defendant was essential to print advertising because it was the dominant newspaper; there was no effective substitute. The synergy for advertisers was that each ad attracts more readers. This happens both directly (readers want to see more advertisements in one place) and indirectly (the newspaper has more resources to gather news). Thus, even though access was denied to customers instead of rivals, the key feature of an essential facilities claim - synergy - remained. The Court did not discuss which structures would constrain pricing, presumably because it believed the Journal would offer the same terms to any advertiser. But it did order sharing. Otter Tail ${ }^{54}$ involves a private utility company that operated two distinct businesses. The first transmitted electricity over long distances. Here, prices were negotiated on the open market backed by public rate-setting when the parties failed to agree on terms. This business seems to have produced only modest profits. The second business was selling electricity to homes and businesses in the municipalities where it transmitted power. Prices were determined by long-term contracts which were so favorable that they generated ninety percent of Otter Tail's revenue. ${ }^{55}$

In the late 1960s, several municipalities began to establish their own municipal distribution systems when Otter Tail's franchises expired. ${ }^{56}$ This strategy, however, could only be implemented by paying Otter Tail to "wheel" the power from distant generating plants. Not wanting to lose its profitable retail business in the municipalities, Otter Tail refused. ${ }^{57}$

The District Court ordered Otter Tail to interconnect at whatever “compensatory” rates and terms the Federal Power Commission (FPC) required. ${ }^{58}$ The Supreme Court affirmed, adding that the FPC had the authority to set rates for transmitting and wheeling power. ${ }^{59}$

${ }^{52}$ Id. at 155 .

${ }^{53}$ Id. at 155 .

${ }^{54}$ Otter Tail Power Co. v. US, 410 U.S. 366 (1973).

${ }^{55}$ Id. at 387.

${ }^{56}$ Id. at 371 .

${ }^{57} I d$. at 368 .

${ }^{58}$ Id. at 375 .

${ }^{59} \mathrm{Id}$. at note 7 (FPC power to order interconnection includes power to prescribe compensation and reimbursement”) Joseph R. Coker, "Saving Otter Tail: The Essential Facilities Doctrine and Electric Power Post-Trinko” 33 Fla. St. U.L. Rev. 231 (2005) (Court “ordered Otter Tail to give the municipalities access to its transmission lines but delegated the more difficult task--the terms of such access--to a 
Otter Tail's transmission capacity was clearly "essential” to the provision of municipal power in the sense that it was economically infeasible for a local municipality to duplicate it. Moreover, sharing was physically feasible in that it did not damage Otter Tail's ability to serve other customers. ${ }^{60}$ Importantly, Otter Tail had built the power lines knowing that it could only earn revenue by carrying power at a regulated price. ${ }^{61}$ If Otter Tail preferred to leave capacity unused, there had to be an indefensible reason. ${ }^{62}$

The Court emphasized that there were no "engineering factors" that would prevent service by Otter Tail's shared facility (the transmission lines). ${ }^{63}$ The transmission lines in Otter Tail were similar to the facilities in Terminal Railroad and AP in that they had unused capacity which made sharing efficient. The problem of efficient pricing was already solved in Otter Tail by regulation, but nondiscrimination in the "wheeling" of power was outside the statute. Otter Tail was trying to exploit this regulatory gap to leverage power over its regulated transmission lines into a more profitable adjacent market, municipal power. "The record makes abundantly clear that Otter Tail used its monopoly power in the towns in its service area to foreclose competition or gain a competitive advantage, or to destroy a competitor, all in violation of the antitrust laws." ${ }^{64}$ This foreclosure is what the District Court redressed, with agreement from the Supreme Court.

While Terminal Railroad and AP can be understood as Section 1 cases, Otter Tail was a Section 2 case. By the late 1970s the Courts' newfound willingness to find that facilities were “essential” had invited a flood of lower court litigation involving access to such disparate facilities as stock exchanges, produce markets, real estate listing services, electricity and gas

regulatory agency.”) Justice Stewart dissented, arguing that Congress has deliberately refrained from making line operators into common carriers. Id. at 384

${ }^{60}$ Id. at 381.

${ }^{61}$ As the Supreme Court later recognized, Otter Tail "was already in the business of providing a service to certain customers (power transmission over its network), and refused to provide the same service to certain other customers.” Verizon Comms., Inc. v. Law Offices of Curtis V. Trinko, 540 U.S. 398 (2004).

62 Justice Stewart addressed this issue in his dissent by noting that "As a retailer of power, Otter Tail asserted a legitimate business interest in keeping its lines free for its own power sales." Id at 374. However, this argument assumes that Otter Tail's retail business had some chance of filling its lines to full capacity. In fact, the rise of municipal power systems suggests that the opposite was happening and that Otter Tail's retail business was shrinking.

${ }^{63}$ Id. at 378.

${ }^{64}$ Id. at 377 . 
networks, airports, sports stadiums, phone systems, ${ }^{65}$ raw materials, contracting advantages, ${ }^{66}$ replacement parts, IP licenses, airline reservation systems, harbor/railroad facilities, power generation or phone networks, airport landing and takeoff slots and ground services, ${ }^{67}$ two way billing, voice mail, ${ }^{68}$ cell phone roaming contracts, and short haul rail lines. ${ }^{69}$ The doctrine reached its most expansive form in MCI Comms. Corp. v. American Tel. \& Tel. Co. ${ }^{70}$

The issue in MCI was that MCI wanted to interconnect with AT\&T's local telephone exchanges so that it could compete in the long-distance telephone market. AT\&T refused and used stalling tactics to stop regulators from intervening. MCI brought claims against AT\&T under Section $2 .^{71}$ Eventually the interconnection issue was solved because, in a parallel case, AT\&T was being broken up into local exchanges and long distance service. ${ }^{72}$ However, MCI also sought damages for AT\&T’s past refusals to interconnect, and won. The trial court awarded $\$ 600$ million in actual damages, leading to treble damages $\$ 1.8$ billion. An important consequence of the case is that sharing became a duty in its own right instead of being a remedy and alternative to divestiture.

Crucially, the Court reinvents Terminal Railroad as a case about leveraging and refusal to deal, forgetting the synergies point. AT\&T's refusal to interconnect thus became an attempt to leverage its power over the local exchanges into a monopoly position in long distance service: "Such a refusal may be unlawful because a monopolist's control of an essential facility (sometimes called a "bottleneck") can extend monopoly power from one stage of production to

${ }^{65}$ Lipsky (1999)

${ }^{66}$ Northwest Wholesale Stationers, Inc. v. Pacific Stationery \& Printing Co., 472 US 284 (1985).

${ }^{67}$ Sergio Baches Opi, “The Application of the Essential Facilities Doctrine to Intellectual Property Licensing in the European Union and the United States: Are Intellectual Property Rights Still

Sacrosanct?” 11 Fordham Intell. Prop. L.J. 409-507 (2001)

${ }^{68}$ Marissa A. Piropato, “Open Access and the Essential Facilities Doctrine: Promoting Competition (2000).

${ }^{69}$ Pitoffsky, Patterson and Hooks, supra at 459.

${ }^{70}$ MCI Comms. Corp. v. American Tel. \& Tel. Co., 708 F.2d. 1081 (1982). MCI has become the "standard statement of the doctrine." Lao, supra at 564.

${ }^{71}$ Id. at 1093. More specifically, plaintiffs claimed that MCI had "Unlawfully denied interconnections for FX and CCSA services; charged MCI excessive and discriminatory interconnection rates for local distribution; harassed MCI through delays, improper installation and maintenance.” Id. at 1096.

${ }^{72}$ Id. at 1110 (noting that regulators and congress were implementing "sweeping” changes and "massive restructuring” to address "larger concerns about broad pro-competitive policy, economic concentration, and political power.”) 
another, and from one market into another. Thus, the antitrust laws have imposed on firms controlling an essential facility the obligation to make the facility available on nondiscriminatory terms.”

Both MCI and Otter Tail involve the synergies of a physical network. In Otter Tail, the physical network consists of the transmission capacity, and in MCI, the physical network consists of AT\&T's control over local exchanges. In both cases, the issue before the Court was that the owner of the essential facility (the network) was trying to leverage its power over the essential facility (the network) into an adjacent market. In Otter Tail, the adjacent market was distribution of power to municipalities. In MCI, the adjacent market was long-distance telephone service.

The two cases together divert the purpose of sharing away from its original purpose, which was to harness synergies, to another purpose, which is to prevent leveraging into an adjacent market. It is the open access feature of sharing that accomplishes this. Even if the main reason for open access is to maximize the synergies that are available through sharing, open access has an important side benefit, namely to limit the facility owner from leveraging power over the facility into adjacent markets.

The MCI Court also rationalizes 1970s-era lower court case law to frame what have since become the conventional elements of an essential facilities claim: ${ }^{73}$

1. control of the essential facility by a monopolist;

2. a competitor's inability practically or reasonably to duplicate the essential facility;

3. the denial of the use of the facility to a competitor; and

4. the feasibility of providing the facility.

In $M C I$, the first and third elements were reasonably clear. The second element (inability to duplicate) qualified the concept of “essentiality" by adding that plaintiff must not be able to duplicate the facility on its own. This would have been simple enough to understand if limited to physical or technical impossibility, but the Court made it clear that economic and regulatory obstacles as well as business reasons would suffice. ${ }^{74}$ In practice, the issue seemed to turn on

\footnotetext{
${ }^{73}$ Herbert Hovenkamp, Federal Antitrust Policy: The Law of Competition and Its Practice (West 2011) at 337. ("In MCI, the Seventh Circuit stated the essential facility doctrine in a way that has influenced numerous subsequent decisions.”)

${ }^{74} \mathrm{Id}$. at 1133 (explaining that it was not "economically feasible” for MCI to duplicate Bell's local facilities "involving millions of miles of cable and line to individual homes and businesses," that "regulatory authorization could not be obtained for such an uneconomical duplication," and that "No legitimate business or technical reason was shown for AT\&T's denial of the requested interconnections.”)
} 
whether plaintiff would normally be expected to construct the facility in the course of building its network. ${ }^{75}$ But when was that? One natural economic argument would have been to say when plaintiff's own business was not large enough to build a facility that could achieve economies of scale. In fact, the Court said nothing.

Finally, the Court provided little guidance on the fourth element (feasibility of sharing). Infeasibility had been fairly obvious for simple assets like railway bridges and news stories. However, the US phone system was easily the most complex technology of its time. Claiming that sharing would not degrade the system would be one thing, but proving it would be another. In the end, the Court threw up its hands and relied on regulators' expertise to establish the point. ${ }^{76}$ In doing so, it left the question of when courts were competent to intervene in complex markets.

We now come to Aspen Skiing ${ }^{77}$, which is one of the most confusing cases in the canon. Here the facilities were four ski mountains. ${ }^{78}$ As in Terminal Railroad, the facilities were originally operated by separate proprietors, but by the late 1960s, ownership had been consolidated so that the plaintiff and defendant were the only two ski operators left. The defendant controlled three of four mountains. At first, the parties cooperated by selling a joint lift pass to all four mountains. This produced an important marketing synergy since skiers only had to stand in line once to ski all four mountains, and the Court accepts as a fact that skiers are better off having access to all four mountains. Separate lift tickets would force skiers to choose between standing in line twice or limiting themselves to a subset of the available mountains. ${ }^{79}$ Apparently the defendant benefited from forcing skiers to make this choice, since the defendant had more mountains to offer.

\footnotetext{
${ }^{75}$ Id. at 1148 ("There was no sufficient explanation as to why MCI, on the one hand, was building its own network, and, on the other, was entitled to access in the interim to AT\&T's facilities. Thus, the jury lacked sufficient evidence to conclude that these interconnections were essential).

${ }^{76}$ The Court also invoked regulators' opinion as additional evidence that duplication would not be feasible. Id. at 1146-47 ("FCC itself characterized service within the LDAs as "essential" even though the new carriers had an option to duplicate them.”)

${ }^{77}$ Aspen Skiing, 421 US 585 (1985).

${ }^{78}$ Id. at 588-89. The region had originally been served by three mountains operated by three separate ski companies. A fourth mountain was added in 1967. The Court argued that it was not feasible for plaintiff to develop additional mountains because of topography, financing, regulatory barriers, and political opposition.

${ }^{79}$ Id. at 605.
} 
The Court ordered the parties to sell a combined lift ticket. The Court justified this order on the theory that it would restore "a pattern of distribution" that had existed in the competitive market "for several years." 80

Aspen was novel because sharing would require the parties to set ticket prices jointly. This seemed to invite collusive price setting in violation of Section $1{ }^{81}$ Earlier cases had avoided collusive price setting either because there was regulatory oversight (MCI, Otter Tail) or because non-profit entities were created to set prices (AP, Terminal Railroad). The sharing in Aspen had a new structure, namely, the price was jointly set and the revenues were shared according to the number of skiers who used each mountain. ${ }^{82}$ This forced the parties "to compete for the daily loyalties of the skiers that had purchased the tickets" ${ }^{83}$ so that any collusive profit would be redistributed to skiers in the form of "free" amenities. ${ }^{84}$

The most famous peculiarity of the Supreme Court's opinion in Aspen is that it nowhere uses the words "essential facility." This persuaded lower courts to restyle essential facilities cases as monopolization or attempted monopolization cases. ${ }^{85}$ Nevertheless, the Supreme Court seemed to acknowledge an essential facilities doctrine as recently as $1999 .^{86}$

The first (and so far only) US case to interpret essential facilities in the IP context was Intergraph Corp. v. Intel Corp. ${ }^{87}$ Intergraph had traditionally made workstations using chips containing its

\footnotetext{
${ }^{80} I d$. at 604 As Prof. Hovenkamp notes, the Court must also have understood that shared lift tickets were routinely used and known to be efficient "in ... other markets” around the country. Hovenkamp IIIB at 212.

${ }^{81}$ Id. at 598 (recounting defense argument "that there clearly cannot be a requirement of cooperation between competitors.")

${ }^{82}$ Id. at 591

83 "Moreover, Highlands wanted to continue to divide revenues on the basis of actual usage, as that measure of distribution allowed it to compete for the daily loyalties of the skiers who had purchased the tickets.” Id. at 592.

${ }^{84}$ The scheme had the potential weakness that the parties' ability to add amenities to ski slopes could well encounter diminishing returns. This would not matter, however, if the competition extended to cash rebates.

${ }^{85}$ Sergio Baches Opi, “The Application of the Essential Facilities Doctrine to Intellectual Property Licensing in the European Union and the United States: Are Intellectual Property Rights Still Sacrosanct?” 11 Fordham Intell. Prop. L.J. 409-507 (2001) at 438.

${ }^{86}$ ATT v California, 525 U.S. 366 (1999) “The incumbents argue that § 251(d)(2) codifies something akin to the "essential facilities" doctrine of antitrust theory... opening up only those "bottleneck" elements unavailable elsewhere in the marketplace.”)

${ }^{87}$ Intergraph Corp. v. Intel Corp., 195 F.3d 1346 (Fed. Cir. 1999).
} 
own patented "Clipper" technology. In 1993 it switched to using Intel chips instead. Four years later, Intergraph sued Intel for violating its patents. Intel retaliated by terminating Intergraph's access to special proprietary information and pre-release products. ${ }^{88}$ Intergraph sued on the theory that Intel's information and products were an "essential facility" under Section 2. The district court granted a preliminary injunction but the Federal Circuit reversed.

The Federal Circuit relied on the fact that Intergraph and Intel did not compete in the same market. Intergraph made workstations while Intel made chips. Since the parties were neither actual nor potential competitors, the Court found that there was no threat to competition under the antitrust laws. ${ }^{89}$ The Court distinguished Otter Tail, Aspen, and MCI on the ground that each had involved some attempt to monopolize direct competition with the defendant's facility (MCI, Aspen) or involved an attempt to monopolize a downstream market where defendant and plaintiff competed (Otter Tail). ${ }^{90}$ The essential facilities claim did not fail because intellectual property was implicated, and therefore the case does not resolve whether intellectual property might constitute an essential facility in U.S. law.

Finally we come to Trinko, in which the Supreme Court expresses skepticism about whether the essential facility doctrine exists at all.

In Trinko, Verizon Communications operated a local telephone exchange, and the service provider AT\&T wanted to offer telephone services as well under the Telecommunications Act of 1996. ${ }^{91}$ AT\&T claimed that Verizon failed to provide adequate access. AT\&T customer Trinko brought a class action against Verizon under the Sherman Act, claiming that he had been injured when Verizon denied its essential facility (the local telephone exchange) to competitors ${ }^{.92}$ The Second Circuit held that Trinko had stated a valid antitrust claim. ${ }^{93}$

The Supreme Court reversed on the narrow ground that Congress had already provided for access to the local telephone exchange under the 1996 Act. ${ }^{94}$ However, the Court did not stop

\footnotetext{
${ }^{88}$ Id. at $1349-50$.

${ }^{89} \mathrm{Id}$. at 1355.

${ }^{90} I d$. at 1357.

${ }^{91}$ Pub. L. No. 104-104, 110 Stat 5.

${ }^{92}$ Id. at 404.

${ }^{93}$ Id. at 405.

${ }^{94} I d$. at 408 (Antitrust actions to compel sharing do not exist in cases where "a state or federal agency has effective power to "compel sharing and to regulate its scope and terms.”)
} 
there. Instead, it presented an extended and largely hostile view of the essential facilities idea, declaring that the Court had "never recognized such a doctrine." ${ }^{95}$ Forced sharing, the Justices added, had "uncertain virtue." ${ }^{\text {" }}$ While Aspen Skiing was "at or near the outer boundary of $\S 2$ liability,"97 Aspen itself was limited to the special case in which defendant's actions in terminating "a voluntary (and thus presumably profitable) course of dealing" showed that it was willing to sacrifice "short-term profits to achieve an anticompetitive end." ${ }^{\text {"B }}$ By comparison, Verizon had never sold local telephone services to the public except when forced to do so on terms and rates set by Congress. ${ }^{99}$ The Court went on to warn that forced sharing ran a significant risk of "false positives" that would punish defendants for refusals that "might have nothing to do with exclusion. ${ }^{100}$ It also promised to mire courts in relief that they could not adequately supervise. ${ }^{101}$ Here the Court seems to have absorbed the idea that an essential facilities doctrine, if it were to exist, would be about preventing leverage, and not about the "lost" message of Terminal Railroad, namely, that synergies should be protected.

Trinko suggests that there is an enhanced duty to share when the defendant had shared in the past, but sharing has been abandoned. The Trinko Court distinguishes Aspen on the basis that the ski resorts had previously shared the marketing of joint lift tickets. There had also been a previous sharing arrangement in Otter Tail (in that Otter Tail had wheeled power to the plaintiff municipality), and the Supreme Court restored that arrangement. In finding that Aspen is at the outer limits, the Court seems to suggest that, absent a previous sharing arrangement, sharing should not be required.

But if our theory about synergies is correct, it should not matter whether firms have made previous business decisions to share or not to share. The firms' past behavior might give evidence that synergies exist and we should be suspicious if companies refuse, but this is only evidence, and not the principle that creates a duty to share. The decision not to share can be made for many reasons, including that the parties feared Section 1 liability or that they simply missed a profit opportunity. The hard question is whether the absence of previous sharing arrangements is

${ }^{95}$ Id. at 408. The Court did, however, stop short of “repudiat[ing] it here.”Id.

${ }^{96}$ Id. at 408 .

${ }^{97}$ Id at 409.

${ }^{98}$ Id at 409 (emphasis original).

${ }^{99}$ Id at 409 - 410. By contrast, some lower courts had already used the doctrine to compel sharing of stadiums and pipelines which had not previously been offered to the public. Hovenkamp, supra, Vol. IIIB at 225 .

${ }^{100}$ Id. at 414 .

${ }^{101}$ Id. at 414 . 
dispositive in the other direction. If the firms had not previously shared, should the Court ever force sharing? Should it ever conclude that the value of the synergies outweighs the possibility of "false positives?" We return to this question in section VI.

\section{Europe Extends the Debate}

We begin by mentioning some cases that were decided as early as the 1970's, and conclude with Microsoft. ${ }^{102}$ For the most part, these cases were decided in ways that would have been familiar to U.S. judges. Indeed, the European Court of Justice's Bronner decision, ${ }^{103}$ which limited the essential facilities doctrine, foreshadowed Trinko in several ways. More recently, however, European courts have aggressively extended the concept of an essential facility to include intellectual property. This can be seen as a departure from U.S. practice, although it might be more accurate to say that the European Commission is entering territory where U.S. precedents are thin to non-existent. In the process, European courts have raised important issues about the extent to which essential facilities based on intellectual property can and should be treated differently from physical assets.

Commercial Solvents ${ }^{104}$ is generally taken as the first important European case. The defendant held a dominant position in the materials used to make an industrial chemical, ethambutol, and supplied a manufacturer named Zoja. Zoja suspended its order for some years, and then wanted to resume. Meanwhile Commercial Solvents had changed its supply strategy, and refused. The Court of Justice held this to be an abuse of dominance, on grounds that Zoja had no feasible alternatives. For Zoja to supply its own raw material would be prohibitively expensive.

To interpret Commercial Solvents as an essential facilities case as we understand the term, we must interpret Commercial Solvent's unique ability to supply an essential raw material as defining an essential facility, and we would have to see a synergy among firms who share the facility, the facility being the capacity to supply the raw material. In that sense, a production plant for raw materials is not too different from a railroad bridge, and the production capacity should be shared. However, the economic consequences of sharing are entirely different in the two cases. In Terminal Railroad, the Court could control the price of the input by insisting that the holding company for the essential facility not earn profit. There is no comparable provision for controlled pricing in Commercial Solvents. The Court has nothing to say about the price at which the raw material would be made available to Zoja.

\footnotetext{
${ }^{102}$ Case COMP/C-3/37.792, EC Commission v. Microsoft.

103 Oscar Bronner GmbH \& Co. KG v. Mediaprint Zeitungs- und Zeitschriftenverlag GmbH \& Co. KG, Case C-7/97, 1998 E.C.R. 1-7791, [1999] 4 C.M.L.R. 112.

${ }^{104}$ Istituto Chemioterapico Italiano S.p.A. and Commercial Solvents Corporation v. Commission, Joined Cases 6/73 \& 7/73, 1974 E.C.R. 223, [1974] 1 C.M.L.R. 309.
} 
In Port of Rodby ${ }^{105}$, a publicly owned port became indispensable for shipping when the Danish government denied a Swedish shipping company a permit to construct its own private facility. At the same time, the Port denied the Swedish company access to its own facilities. The Port argued that the plaintiff had not established that there was unsatisfied demand for ferry service, and that entry would simply detract from their own business. The Commission rejected this argument, and also stated that "the Port of Rodby was not saturated." On this basis the Commission required that the Port either share its existing facilities or allow the plaintiff to build a new facility. The opinion does not comment on terms of access.

On the facts understood by the Commission, the Port exhibited the synergy always present in natural monopoly with unused capacity, and thus the case is consistent with the idea that there should be open access when there are substantial synergies.

Magill $^{106}$ concerned program listings of three television broadcasters in Ireland. When the plaintiff Magill tried to improve his TV listing service by listing the programming for an entire week, instead of the more limited periods he previously published under license, the three broadcasters sued for copyright infringement. In upholding the judgment for Magill, the European Court of Justice says that the conduct "thus prevented the appearance of a new product, a comprehensive weekly guide to television programmes, which the appellants did not offer and for which there was a potential consumer demand," ${ }^{107}$ which is an "abuse", 108 and that "(t)he applicants were thus using their copyright in the programme listings ... to secure a monopoly in the derivative market of weekly television guides..." The ECJ adds that "The Court of First Instance also regarded it as significant in that regard that the applicants had authorized, free of charge, the publication of their daily listings and highlights of their weekly programmes in the press in both Ireland and the United Kingdom."109

According to unofficial, if semi-public, gossip, the Commission was moved by the fact that TV listings were an "unmeritorious" species of IP. ${ }^{110}$ Perhaps they thought the IP was trivial, and

${ }^{105}$ Commission Decision 94/119/EC, 1994 O.J. (L 055) 52.

${ }^{106}$ Radio Telefis Eireann (RTE) and Independent Television Publications Ltd (ITP) v. Commission, Joined Cases C-241/91 P \& C-242/91 P, 1995 E.C.R. 1-743, [1995] 4 C.M.L.R. 718.

${ }^{107}$ Id. at para. 54.

${ }^{108}$ Id. at para. 54 .

${ }^{109}$ Id. at para. 29.

${ }^{110}$ Opi, supra at 461. ("Professor Korah reports that officials of the Commission's legal service pointed out, in their personal capacities, that Magill should be limited to 'unmeritorious kinds of intellectual property."”) 
the incentive provided by copyright was superfluous, since other, non-trivial incentives already existed to make the listing. Defendant could not sell its product (broadcasting) without also having a program listing. The incentive to produce and disseminate programs will be the same irrespective of whether the broadcasters are protected from competition in the television guide market."111

In Magill there were actually three essential facilities -- the program listings -- which could be combined to create a joint product with synergies. The usefulness to viewers of the joint listing was in their ability to compare program listings side-by-side in a given time slot. The Commission, endorsed by the ECJ, opens the use of these listings to all entrants, not just to the plaintiffs. The ECJ endorses the Commission's requirement that the three broadcasters put an end to their "breach" by "supplying ... third parties on request and on a non-discriminatory basis with their individual advance weekly programme listings and by permitting reproduction of those listings by such parties". ${ }^{112}$

The concept of "essential" in Magill clearly means that there were no feasible substitutes. In Magill, there is literally no substitute, while in Commercial Solvents, Otter Tail and MCI, substitutes were simply infeasible at reasonable cost. However, Magill differs from Commercial Solvents, Otter Tail and MCI in that the defendant broadcasters were not trying to leverage their control over the essential facility into an adjacent market - the weeklong TV guide - but were rather trying to leave the market unsupplied. Commercial Solvents differs from the other three cases in that the synergy is simply an economy of scale. By ordering sharing, the court harnessed this synergy, but did not control pricing of the input. Given that the raw material is still controlled by a monopolist, it is hard to see how "competition” would be an improvement for consumers. The court does not comment on this.

In Bronner, ${ }^{113}$ the defendant was a dominant newspaper publisher with a home-delivery system. Plaintiff was a small publisher that wanted to share the home-delivery system. Defendant argued that making its system available to all Austrian publishers would lead to congestion by "exceed[ing] the natural capacity of its system," 114 and that it would allow competitors to freeride on its "great administrative and financial investment." ${ }^{115}$ Moreover, it had never shared its facilities on anything resembling the terms requested. ${ }^{116}$

\footnotetext{
${ }^{111}$ Opi, supra at 460.

${ }^{112}$ Id. at para. 12.

${ }^{113}$ Oscar Bronner GmbH \& Co. KG v. Mediaprint Zeitungs- und Zeitschriftenverlag GmbH \& Co. KG, Case C-7/97, 1998 E.C.R. 1-7791, [1999] 4 C.M.L.R. 112.

${ }^{114} I d$. at para. 9.

${ }^{115}$ Id. at para. 9.
} 
The Court declined to enforce sharing, explaining that plaintiff could negotiate equally advantageous sharing arrangements with other parties or create its own distribution system. ${ }^{117}$ Even small players could achieve the required economies of scale. ${ }^{118}$ Sharing was not required to maintain the viability of the plaintiff newspaper.

On first reading, this case seems out of line with the theory of essential facilities we will articulate below, namely, that sharing should be required whenever it provides synergies and can be achieved on terms that do not compromise competition. The potential synergy in Bronner is that the plaintiff and defendant can reduce costs by sharing the defendant's unused capacity. However, in declining to force sharing, the Court does not rely on any argument about capacity. Instead it relies on the argument that, absent sharing, there is no impediment to the plaintiff serving the market. It can use a different distribution system. The argument is that even though sharing might be efficient, it is not necessary for competition in the market.

Does the Court thereby give up on the synergies available from sharing? No! If the defendant will face competition from the plaintiff in any case, then the defendant has an incentive to offer sharing on terms that reduce costs and make both firms better off. Intervention by the Court should not be necessary to achieve sharing - the market should solve it. This reasoning is not explicit in the case, but it allows us to reconcile Bronner with Commercial Solvents and Terminal Railroad. In all three cases, the defendant(s) had unused capacity, but in the latter two cases, they were ordered by the court to share it.

Why would it make sense for the court to order sharing in Terminal Railroad and Commercial Solvents, but not in Bronner? The cases differ in an important way, articulated by the court. In Commercial Solvents and Terminal Railroad, it was impossible to enter the market without sharing the defendant's unused capacity. By refusing to share, the defendants could keep the rivals out of the market. This was not true in Bronner. As a consequence, sharing was much

\footnotetext{
${ }^{116} I d$. at para. 9 ("It adds that the position of Wirtschaftsblatt is not comparable to that of Der Standard, since the publisher of the former also entrusted the Mediaprint group with printing and the whole of distribution, including sale in kiosks, so that home-delivery constituted only part of a package of services.") and para. 30 (denying relief on ground that service had not been made available to other parties except where "other services were not entrusted to Mediaprint at the same time.”)

${ }^{117}$ Id. at para. 44 ("Moreover, it does not appear that there are any technical, legal or even economic obstacles capable of making it impossible, or even unreasonably difficult, for any other publisher of daily newspapers to establish, alone or in cooperation with other publishers, its own nationwide home-delivery scheme and use it to distribute its own daily newspapers.”)

${ }^{118}$ Id at para. 45 ("It should be emphasised in that respect that, in order to demonstrate that the creation of such a system is not a realistic potential alternative and that access to the existing system is therefore indispensable, it is not enough to argue that it is not economically viable by reason of the small circulation of the daily newspaper or newspapers to be distributed.”)
} 
more likely to arise as a private arrangement in Bronner than in Commercial Solvents or Terminal Railroad. And even if the sharing arrangement did not materialize, there would still be competition in the market.

Intriguingly, Bronner distinguishes Magill on grounds that the sharing rules for IP could be markedly different. ${ }^{119}$ In retrospect, this opened the door to a radically expanded doctrine.

In IMS Health ${ }^{120}$, IMS was a market research company that provided regional data reporting services to pharmaceutical companies, regarding sales of pharmaceutical products throughout Germany. These reports were based on data purchased from pharmaceutical wholesalers, which were checked and formatted according to a brick structure. Each brick represents a geographical area with at least four to five pharmacies. IMS has refined its brick structure since its inception in 1969 with the help of the pharmaceutical industry. IMS brought a copyright infringement suit against two competitors, AzyX and NDC, which it suspected were selling data reports based on the same 1860-brick structure.

The Commission ordered IMS to license the brick structure, finding evidence of what economists call network effects. Any report formatted according to a new structure would have to be "translated" into the 1860-brick structure in order to allow pharmaceutical companies to compare data from earlier years and from third parties, who also use the 1860-brick structure. Because it would be costly and inconvenient, many pharmaceutical companies had said they would not be willing to switch to another standard. There were also legal and technical structures which limited the choice of alternative bricks. The brick structure had become "de facto industry standard.”

Here, the brick structure is the essential facility, and the synergy is provided by network effects. As in Magill, the essential facility is intellectual property.

Finally we come to Microsoft, ${ }^{121}$ which also implicates intellectual property. Microsoft refused to provide makers of work group server operating systems with information that would allow their software to operate seamlessly with desktops running on Windows. Microsoft had made this information available for previous versions of Windows. The Commission found that there was "no actual or potential substitute for the refused input" and that Microsoft had used this advantage to achieve a "rapid rise to dominance" in the adjacent market for server operating

\footnotetext{
${ }^{119}$ Id. at para. 43. Distinguishing Magill on grounds that "case-law on the exercise of an intellectual property right" may not be applicable to "the exercise of any property right whatever."

${ }^{120}$ Order of the President of the Court of First Instance of October 26, 2001, IMS Health Inc. v. Commission, Case T-184/01 R, 2001 E.C.R. 11-3193, [2002] 4 C.M.L.R. 2.

${ }^{121}$ Case COMP/C-3/37.792, EC Commission v. Microsoft.
} 
systems. Conversely, letting competitors access the information would allow them to provide "new and enhanced products" to the benefit of consumers. ${ }^{122}$

Microsoft's conduct constituted an abuse of its dominant position under Article $82^{123}$. Microsoft's normal IP rights could not justify this behavior ${ }^{124}$, particularly since Microsoft was not being asked to provide actual software ${ }^{125}$ and there was no danger that the disclosures would help competitors to clone Windows. ${ }^{126}$ The Commission ordered Microsoft to provide its information to competitors on "reasonable and non-discriminatory terms". To the extent that remuneration was required, it could not "reflect the strategic value stemming from Microsoft's market power" over operating systems for PCs or servers. ${ }^{127}$ Here the Commission addresses the two problems we mentioned at the beginning of Section II: It is structuring the sharing terms in a way that limits Microsoft's use of market power, and controlling leverage over the adjacent server market by ordering that the sharing be nondiscriminatory.

The case led to backlash and criticism, and in 2009 the European Commission published Guidance to their enforcement policy. ${ }^{128}$ The Guidance defines a facility as indispensable or essential, "where there is no actual or potential substitute on which competitors in the downstream market could rely so as to counter - at least in the long-term - the negative consequences of the refusal. In this regard the Commission will normally make an assessment of whether competitors could effectively duplicate the input produced by the dominant undertaking in the foreseeable future." 129

The Guidance elaborated the Commission's view by arguing that the dominant undertaking could not charge a price so high that "an equally efficient competitor could not trade profitably in the downstream market.” The benchmark for this inquiry would be the dominant firm’s own long

\footnotetext{
${ }^{122}$ Id. at para. 18

${ }^{123}$ Id. at para. 19

${ }^{124}$ Id. at para. 20

${ }^{125}$ Id. at para. 18

${ }^{126}$ Id. at para. 21

${ }^{127}$ Id. at para. 31
}

${ }^{128}$ Guidance on the Commission's enforcement priorities in applying Article 82 of the EC Treaty to abusive exclusionary conduct by dominant undertakings, Official Journal C 045, 24/02/2009 P. 0007 0020.

${ }^{129}$ Id. at para. 83 
run average incremental cost (LRAIC) in the downstream market. ${ }^{130}$ Facilities would not be deemed essential would "normally" depend on whether competitors could effectively duplicate the input produced by the dominant undertaking in the foreseeable future."131 While intervention would not be limited to cases where the good had been supplied before, past sales would make the case for sharing stronger by showing that the owner would receive "adequate compensation." The dominant company could, however, rebut this by showing that circumstances had changed. ${ }^{132}$ The most likely consumer harm seen by the Commission is where refusal would prevent competitors from "bringing innovative goods or services to market” or conducting "follow-on innovation." 133 However, the dominant firm could rebut this by arguing that supply would interfere with its ability to earn an adequate return on its investment and therefore "continue to invest in the future."134 The dominant firm could also argue that supply would interfere with its own ability to innovate by bringing about "structural changes" including "the development of follow-on innovation by competitors. ${ }^{135}$

\section{Essential facilities and synergies}

The cases above are the ones most cited for the essential facilities idea. A difficulty in making sense of them is that synergy has become tangled up with other legal concepts like leveraging (in particular, leveraging power over the essential facility into another market) and general refusals to deal. In this section, we ask whether the above cases were correctly decided on the basis of synergy or must instead be understood (if at all) as preventing leveraging or as following from some other principle beyond this article. We point out why a duty to share based on synergies, properly implemented by the court, can also provide an antidote to leveraging.

A threshold question is when there is a duty to share. That takes us into murky terrain that courts and commentators have mostly avoided. Any definition of "essential facility" runs the risk of producing a theory that takes in too much territory. On the other hand, if no definition is possible, there is something wrong with the theory.

We propose that the elements of an essential facilities claim should be

\footnotetext{
${ }^{130}$ Id. at para. 80

${ }^{131}$ Id. at para. 83

${ }^{132}$ Id. at para. 84

${ }^{133}$ Id. at para. 87

${ }^{134}$ Id. at para. 87

${ }^{135}$ Id. at para. 89
} 
1. Sharing the facility would create synergies by
a. improving the qualities of the members' products, or reduces industry unit costs of producing them, while

b. not raising the defendant-owner's costs or restricting its ability to produce.

2. The sharing can be structured to avoid cartelization in a way that

a. makes consumers better off than without sharing, and

b. preserves the incentive to invest in the facility in the first place.

3. The defendant-owner has nevertheless refused to share.

Our elements do not contradict existing law, but they refocus attention on Terminal Railroad's original goal of preserving synergies, making that concept more central and more precise. Our elements differ slightly from the EC's Guidance, ${ }^{136}$ which ignores synergy, and focuses on the lack of feasible substitutes for the facility. Our elements similarly improve on the $M C I$ elements, which define "essential facility" in terms of "a competitor's inability practically or reasonably to duplicate the essential facility." Introducing synergy makes these formless and undefined concepts unnecessary.

One might ask whether the synergy concept should not go even further, to include any facility with unused capacity. In some of the cases we cite, the facility is duplicable, but duplication would be inefficient because there is unused capacity. The unused capacity can create a synergy in the form of cost reduction.

We believe that the doctrine should not extend to cases where the facility can be feasibly duplicated. The practical reason is that it would drastically expand the number of cases that judges need to consider, and would require mundane inquiries into when and how usage could be expanded without impacting the defendant-owner. However, there is also a deeper theoretical reason, related to whether the owner of an existing facility can keep rivals out of the market by refusing to share.

If entry will occur even without sharing, we would expect a profit-maximizing owner to offer access even without judicial intervention. The incumbent and the entrant can save the cost of

${ }^{136}$ Id. at 83 ("where there is no actual or potential substitute on which competitors in the downstream market could rely so as to counter - at least in the long-term - the negative consequences of the refusal. In this regard the Commission will normally make an assessment of whether competitors could effectively duplicate the input produced by the dominant undertaking in the foreseeable future.”) 
duplication by sharing the existing facility, and they will be competitors in any case. Of course the incumbent might still refuse to share if he will need the excess capacity in the future. This is a market judgment which courts should ordinarily respect.

Suppose, however, that entry would not occur without sharing, either because entry is impossible (for example, because there is only one suitable site for a bridge) or because duplication would be uneconomical for any conceivable alliance of competitors, no matter how well financed. Because entry will not occur, the owner of the existing facility feels no threat, and will not facilitate competition that would otherwise not occur. This is the situation in which the essential facilities doctrine has been invoked. ${ }^{137}$

We recognize, of course, that if the monopolist owner is required to share, and shares the facility at a high access price, the resulting "competition" might not improve the welfare of consumers. Harvesting the synergy of shared capacity will mainly help consumers if cartelization is avoided. ${ }^{138}$ This is why we add the qualifier that there is an appropriate sharing rule that makes consumers better off than without sharing.

In Intergraph, Intel supplied an input, chips, that were impossible to duplicate, but refusing to supply Intergraph did not harm consumers in any obvious way, given that Intergraph had competitors who were still supplied by Intel. On these grounds, we believe Intergraph was correctly decided, although this was not the reasoning of the court. Compare with Commercial Solvents, in which the essential facilities claim succeeded. Commercial Solvents also had unique control over an input, and was ordered to supply the input to Zoja. The case differs from Intergraph in that Commercial Solvents competed with Zoja in the end user market. However, the court does not explain why the order to share might improve consumer welfare. An improvement seems unlikely, given that Commercial Solvents still controlled the price of the input. Without such an argument, we do not see that Commercial Solvents was correctly decided.

Because every potential user of the facility has the same cause of action, the "open access" or "nondiscrimination" aspect of sharing is understood. ${ }^{139}$ The shared facility should be available

\footnotetext{
${ }^{137}$ We thus agree with the distinction made in Bronner. See also Herbert Hovenkamp, Federal Antitrust Policy: The Law of Competition and Its Practice (West 2011)at 316 ("[p]ermitting firms to piggyback on their rivals' investment when they can develop alternative assets for themselves impedes both innovation and competition.") and at 321 ("[I]f antitrust is going to impose a duty to deal on dominant firms, the obligation must be limited to inputs that the competitive market is not realistically capable of producing.")

${ }^{138}$ We do not know of a case where consumers would be better off with sharing at the monopoly price, although with strong enough synergies, that could happen. If there is no way to structure sharing so as to constrain the price, it would then be in the public interest to allow sharing even without a constraint on pricing.

${ }^{139}$ However, in Northwest Wholesale Stationers, Inc. v. Pacific Stationery \& Printing Co., 472 US 284 (1985), the Court recognized an exception and said that exclusion could not be seen as a per se violation
} 
on the same terms to anyone who wants to use it. As we discuss further below, courts have enforced open access. This has had the ancillary benefit of preventing owners of essential facilities from leveraging their power over the facility into adjacent markets.

The sharing arrangements we have in mind would be similar to the nonprofit organizations we saw in Terminal Railroad and Associated Press, although other sharing arrangements might have procompetitive effects as well. The next section categorizes the sharing arrangements that have so far materialized, and explains their virtues. As courts have become more focused on open access to prevent leveraging, the original message of Terminal Railroad, that zeal for antitrust enforcement should not sacrifice the synergies from sharing, has been lost. The prevention of leveraging is incidental to the doctrine, not its essence.

Our two-pronged definition of essentiality may eliminate some of the cases in the canon. In Commercial Solvents, even an efficient and well-financed rival firm could not duplicate the wholesale supply provided by Commercial Solvents, because the raw materials were solely available from Commercial Solvents. The facility creates synergy through its economies of scale. Moreover, the wholesale supply satisfies the EC's definition of essentiality. However, even though sharing seems to provide competition in the downstream market, the case does not tell us (and it is not obvious) that sharing makes consumers better off. The ambiguity arises because the wholesaler maintains control of the input price. If marginal costs are increasing in each firm's production technology, it would be possible that supplying the market with two firms might lower costs, but production will not be efficiently divided between the firms because one of the firms is paying a price above marginal cost for the essential input.

The synergies that must be present in essential facilities come in several forms. Some are physical. In Terminal Railroad splitting the various routes across the Mississippi into competing (and uncoordinated) organizations would have cost more and provided poorer service. A facility can be essential (on a sliding scale) whenever production entails very high fixed costs and an incumbent's production facility has excess capacity. ${ }^{140}$

Facilities can have synergies because they are are nonrival, such as the news stories in Associated Press. It is not economically efficient to produce a nonrival good twice.

In Aspen and Magill, the synergy stems from complements. In Aspen, the dominant firm owned three mountains and its rival owned one. Making all four available under a common lift ticket

of the antitrust laws. There will presumably always be extenuating circumstances where exclusion is reasonable.

${ }^{140}$ Areeda advocates a criterion consistent with Bronner that asks whether the plaintiff could feasibly enter the market without a sharing arrangement. Entry might be feasible even if it is not efficient, that is, even if the incumbent has enough capacity for both firms. 
would have made skiers better off. In Magill the would-be TV guide publisher wanted to combine the dominant firm's listings with those of its rivals. Once again, consumers would have benefited from the synergy. In both cases, the dominant firm preferred to frustrate the synergy on the theory that it could make higher profits that way. For example, defendant in Aspen calculated that forcing skiers to choose which lift ticket to buy would lead to higher sales for its threemountain package rather than the one mountain. The plaintiff (the one-mountain ski company) sought to restore the synergy by proposing many joint marketing arrangements. None was accepted until the Court intervened. In Magill, there was a dominant broadcaster, whose TV listings were an essential ingredient for publishing a weekly TV guide. This firm was the holdout trying to block licensing to the third-party, Magill, who wanted to realize synergies by producing the guide.

In IMS, MCI and Microsoft, the synergies stem from network effects. Networks can be either physical, as in MCI, or virtual. In MCI, MCI wanted to share AT\&T's physical telephone network, which would have been very costly to duplicate. Virtual networks arise when users prefer products that are heavily used by others. Virtual networks are defined by a standard, which defines the network and creates the benefits. If the standard is proprietary, it could well fall within our definition of an essential facility, although as we discuss below, the problems in applying the theory to intellectual property might be disqualifying. ${ }^{141}$ The database structure at issue in IMS is a virtual network. It is valuable to each user precisely because vendors and other users use it. The API's in Microsoft also define a virtual network. The API's gave to third-party developers the ability to contribute their innovations to the Windows network.

\section{Principled sharing rules}

In discrediting the essential facilities doctrine, the Trinko Court does not dwell on structural solutions for how to balance sharing with competition. Instead the Court reminds us that courts are not well positioned to do rate regulation, and therefore they should exercise caution in applying remedies that affect prices. However, Terminal Railroad teaches that sharing can be compelled in ways that constrain prices, and put less burden on the court than actual price setting. In this section, we investigate the price effects of different sharing rules, showing that they have different implications for competition. Our objective is to understand which ones achieve the synergies of sharing while maintaining the price-reducing virtues of competition. The sharing rules we will discuss here are

1. Cost sharing (Terminal Railroad, Associated Press)

2. Revenue sharing (Aspen)

\footnotetext{
${ }^{141}$ One might argue that sharing of APIs was required in the E.C. Microsoft case because of network effects. However this is not a fact asserted or relied on by the E.C. or the Court of First Instance.
} 


\section{Compulsory licensing (Microsoft, Magill, IMS)}

4. Rate regulation and compulsory sales in adjacent markets (Otter Tail,MCI)

Each of the sharing rules should be coupled with an open-access or nondiscrimination requirement. Open access maximizes the benefits from sharing, at least until the facility becomes congested. It also has the ancillary benefit of preventing the owner of the facility from leveraging control over the facility into an adjacent market. We saw such attempts in MCI, Otter Tail, and Magill. Mere control over prices for sharing would not have solved these attempts to leverage control over the essential facility into the adjacent market.

\section{Cost sharing}

In Terminal Railroad, the bridges and ferry were under the control of a subsidiary with a nonresiduary clause. This means that the subsidiary could not earn profit, and therefore must charge fees that sum to the cost of providing the service. There are nuances in calculating cost, such as whether it amortizes the fixed cost or simply allocates the current variable costs. To satisfy the elements above, all costs must be accounted for. Otherwise, anticipating the rule, the incentive to invest in the facility facilities would be undermined.

If the annual costs are $\mathrm{K}$, the easiest way to share the costs is to charge each member railroad an equal fixed share, say $\mathrm{K} / \mathrm{n}$ if there are $\mathrm{n}$ member railroads. Since the assessment is a fixed cost, which does not depend on the railroad's business decisions, it would have no impact on competition except to the extent that small railroad companies might find $\mathrm{K} / \mathrm{n}$ unaffordable and be forced out. If that is not likely, then fixed shares are surely the cost-sharing rule that is best for competition. In fact, the market will be identical to the market that would arise if there were no river to cross.

The fixed shares are nondiscriminatory if the railroad companies are similar in size, but otherwise fixed shares are very burdensome to small railroads, even if they don't go out of business. Two alternative cost-sharing rules would be to share the costs according to the railroads' relative revenue shares, measured in dollars, or according to their demand shares, measured, for example, by bushels of wheat hauled across the river. We show in the appendix that both these rules have an impact on prices, and provided there are the same number of railroads operating, fixed cost shares will lead to lower prices.

Consider, for example, revenue-based cost sharing. This means that if a railroad earns $1 / 5$ of the total revenue earned by member railroads, it will bear $1 / 5$ of the cost.

Suppose further that railroads compete for business by setting their rates. Ordinarily, if a railroad has some excess capacity, it will drop its price a little in order to undercut competitors and fill up the cars. This is the competitive effect that antitrust law is designed to achieve. Even a small 
reduction in the rate will attract more business, and increase the railroad's revenue while also benefiting producers and consumers.

Now suppose instead that the costs are shared according to revenue shares. A railroad company that would otherwise be keen to cut its rates and fill up its cars will now hesitate. On one hand it gets more business and more revenue, but on the other hand, it increases the share of the bridge cost it pays. If the latter is too onerous, it will not cut its rates, or will cut them less. As a consequence, in aggregate, rates will be higher than if this effect were absent. (This is shown more formally in the appendix.) Nevertheless, it might be the best available rule under the constraint that the railroads must share the costs, especially if fixed shares are infeasible due to the problem of shutting out small companies. With revenue-based cost sharing, small companies pay a small portion of the cost, and on a unit basis, are not discriminated against. Furthermore, if many firms share the costs, the effect on equilibrium pricing might be quite small.

The sharing arrangement in Associated Press was similar, except that the revenue shares were approximated by the number of residents in the geographic area served by each newspaper. ${ }^{142}$ This system is more like fixed shares than Terminal Railroad because a successful expansion of readership within the geographic area will not change the cost share. Instead, cost shares only change when the size of the distribution area increases or decreases, and this is not under the control of the publisher.

\section{Revenue Sharing}

In Aspen, the Court found that there were synergies for skiers in having access to the four mountains, and required that the tickets be marketed jointly in order to save skiers from the cruel choice between giving up a mountain and standing in line. The Court praised the historic rule in which each mountain's share of revenue was equal to the proportion of skiers using its slopes.

Unlike Terminal Railroad, the sharing rule in Aspen does not have a nonresiduary clause. Indeed, it would be quite extreme to impose zero profit on the ski resorts, and they would surely prefer to be broken up in the spirit of Standard Oil. The railroads in Terminal Railroad could remain profit centers while sharing the facility on nonprofit terms because the facility was only an input to the final product, which was rail transport. In contrast, the shared facility in Aspen is the product itself.

In the Aspen sharing scheme, nothing constrains the price, and it would be natural to find that the owners charged a monopoly price for the four mountains. That is, the revenue-sharing solution in Aspen threatens to support the kind of cartel that Section 1 is designed to prevent.

\footnotetext{
${ }^{142}$ Associated Press, "Member Choice Product Guide," at 3. http://www.apexchange.com/BizUI/Front1/docs/MemberChoiceProductGuide.pdf.
} 
However, there are two caveats to this conclusion. Even with a monopoly price for access to the four mountains, the owners will still compete because they share the revenue according to usage. To increase usage, they will find ways to give kickbacks to the skiers, perhaps giving them free brandy in the warming huts, or even cash rebates. With rebates, the net pricing could well become competitive again. Rebates are an odd and perhaps unreliable way to achieve competitive pricing, but the incentive to compete should not be underestimated. It does seem plausible that the sharing rule will benefit skiers despite the joint pricing.

\section{Compulsory licensing of intellectual property}

In Microsoft, Magill and IMS, the European Commission required that copyrighted works be made available for free to rivals. In Microsoft, it was the APIs at issue. The Court reasoned that the APIs were a byproduct of producing the operating system, and therefore costless. It therefore would not harm Microsoft to give them away for free. The reasoning in Magill and IMS was similar, as we have discussed.

The cases raise the more general issue of how to handle intellectual property. Intellectual property never gets congested (it is nonrival), and sharing therefore creates synergies as outlined in the elements above. However, our element $2 b$ fails, because it would generally be impossible to structure sharing in a way that preserves the incentive to invest in the first place.

To save the element $2 \mathrm{~b}$ as a conceptual matter, we could try to identify the "cost" of an invention, interpreted as the minimum reward required for efficient investment in the innovation. Then the cost could be amortized over time, with the users paying cost shares to the innovator.

The problem is that it is famously difficult to calculate the efficient reward for an innovation. What evidence would be required? The number of competitors in the innovation process should enter into it, as well as the probability of success. What if the investment should not have been made at all, because otherwise a better alternative would have materialized? In that case, the optimal reward is arguably zero. In the vexed interface between competition policy and intellectual property policy, courts have never been willing to face the problem of calculating the optimal reward. Should we then propose that they solve this problem in the context of an essential facilities doctrine?

One might also object that in providing for intellectual property protection, Congress has already made the judgment that sharing is not economically feasible. Sharing will generally erode the reward to the inventor. The fundamental right granted by intellectual property law is the right to exclude users, and the justification for exclusivity is that it allows the owner earn a reward for his contribution.

But this objection is unpersuasive. Under our interpretation of the essential facilities doctrine, the inventor would still receive her reward. In fact, structured sharing might be an improvement over the current situation where rewards have no relationship to costs. Because the price of a license 
can be controlled by the structure of sharing, the doctrine could help bring the rewards into alignment with costs. The prices for using the intellectual property would be high enough to induce efficient investment, but no higher.

We reiterate, though, that establishing the required reward is daunting and perhaps debilitating. Even the E.C. has not compelled sharing when the intellectual property is costly to develop. Where the EC has compelled sharing, namely, in Microsoft, IMS and Magill, they found that the cost of the intellectual property was zero, and therefore they did not face this problem.

\section{Rate regulation and compulsory sales in adjacent markets}

In Otter Tail, the rate-regulated transmission company threatened to cut off a municipality when the latter announced plans to distribute its own electricity, rather than contracting with Otter Tail to distribute it. Otter Tail had built a transmission grid knowing that they were subject to rate regulation. The only way that Otter Tail could make real profit was to distribute power locally for super-competitive rewards. However, when municipalities decided to terminate these contracts and distribute power themselves, Otter Tail threatened to cut them off from the transmission grid. This was deemed illegitimate. The Court did not have to address the problem of pricing, because transmission prices were regulated, but did require nondiscriminatory access. Otter Tail was not allowed to leverage its power over the essential facility, the transmission lines, into the adjacent market of electricity distribution.

In MCI, the regulated firm was AT\&T, which again owned the transmission lines (this time for long distance telecommunications) and local distribution (the local telephone exchanges). The case was about an entrant, MCI, that wanted to connect its own long distance lines to the local exchange. Again, there was no issue of efficient pricing, because AT\&T's local exchange prices were already regulated. As in Otter Tail, the court imposed an access requirement, which prevented AT\&T from leveraging its power over the essential facility, local telephone exchanges, into the adjacent market of distance transmission.

The apex of essential facilities cases in telecommunications is Trinko, where the Court refused to mandate sharing, on grounds that regulation already takes care of it. The case is different from $M C I$ in that the Verizon was trying to protect the monopoly position of the essential facility itself, the local exchange, rather than trying to leverage into another market.

Rate regulation changes the nature of the essential facilities inquiry, because rate regulation already recognizes the tension between efficient sharing and competitive pricing. The only news in these cases is that the regulated firm is not allowed to use an essential facility to capture an adjacent market. These cases stress the nondiscrimination issue in the requirement to share, rather than the pricing issue. 


\section{Dangling Questions}

The cases that are commonly understood as comprising the essential facilities doctrine raise several additional issues.

Q: In several of the cases, the Court relies on past sharing behavior to justify its order to share. How does this enter the calculus?

Past sharing has been understood by courts as evidence of profitability, for example, in Aspen. However, past sharing should probably not be dispositive, as lawyers might then warn clients that sharing agreements are irreversible. In the long run, this could easily lead to less sharing than ever. In addition, sharing in the past does not necessarily prove that sharing is still sensible or feasible today. In Aspen it was recognized, at least tacitly, that defendants could rebut the argument of past sharing by pointing to other, more innocent changes that made past sharing arrangements obsolete. ${ }^{143}$

Q: What is the role of open-access itself, as distinct from structured sharing that constrains pricing?

We view open access or nondiscrimination as inherent in the essential facilities doctrine. Open access maximizes the beneficial synergies (until the facility becomes congested), while having the ancillary effect of preventing leverage into adjacent markets. The latter effect became particularly salient after MCI reinterpreted Terminal Railroad as a case about leveraging rather than a case about harvesting synergies. ${ }^{144}$

Whatever one thinks about the harm from leveraging, it is not the original rationale for the essential facilities doctrine. The rationale is to harvest synergies. Moreover, the consumer harm from leveraging is disputed. Already in the 1970s, the so-called Chicago School pointed out that monopolists should earn the same profit with or without leveraging. ${ }^{145}$ Their critique can be seen in Commercial Solvents, where the wholesale monopolist of the essential input became a retail supplier, and was required to provide the input to a rival. Because the essential input can be provided at a monopoly price, there is little benefit to creating competition in the downstream

${ }^{143}$ Defendant had, in fact, argued that it wanted to disassociate itself from plaintiff's allegedly inferior skiing services. The jury rejected this argument. Id. at 610 .

${ }^{144}$ Id. at 1132. See also p. 1144. ("Whether we label AT\&T's violation of the antitrust laws as tying or the denial of an essential facility, our prime concern is that AT\&T used its monopoly power in local telephone service as a lever to impede or destroy competition in other markets.”)

${ }^{145}$ For a sophisticated survey of the "one monopoly” objection and related counter-arguments, see. Mats A. Bergman "The role of the essential facilities doctrine" The Antitrust Bulletin/Summer (2001) 403 at 421. 
market for chemicals; there will still be monopoly pricing in that market due to the high price of the input, and the monopoly profit will mostly be collected by the monopolist supplier of the input. Nondiscriminatory access without a pricing constraint will not generally create the benefits of competitive pricing. ${ }^{146}$

In Otter Tail, the consequence of open access was that a nonprofit distributor of electricity, the municipality, took the place of the Otter Tail in the local electricity market. This is the reason that open access helped consumers. If another for-profit distributor had taken the place of Otter Tail instead of the municipality, consumers would not have noticed a difference. It is only if open access supported competition in the municipal market, or a nonprofit provider like the municipality, that open access would have a beneficial effect.

Similarly in MCI, if AT\&T's access prices to the local exchanges were not regulated, then open access would not lead to competitive pricing in long distance transmission.

Q. Are the problems addressed by the essential facilities doctrine a subspecies of problems already addressed as Section 2 violations? (For example, Professor Hovenkamp takes this view.)

We agree that the refusal to share an essential facility can be labeled a species of refusal to deal. Our discussion illuminates a principle behind the unlawfulness of refusal, namely, that facilities should be shared when they provide synergies. Other species of refusal to deal may be rooted in other principles.

Q. Is the essential facilities doctrine likely to arise in Section 1 cases or Section 2 cases of the Sherman Act?

The essential facilities doctrine has been invoked in both ways. Nothing in our analysis would contradict that. Terminal Railroad was decided under both sections. Section 1 is likely to be invoked when someone sues a cluster of firms that have made a contract to share a facility but to exclude rivals, as in Terminal Railroad or Associated Press. Section 2 is likely to be invoked when someone sues a single owner of a facility for access, as in Otter Tail and MCI. In both situations, the relevant aspects of the essential facilities doctrine are open access for rivals on terms that constrain the exercise of market power. The doctrine as we have reformulated it states when sharing should be required (a fortiori, when it should be allowed), and also sets the conditions of sharing that would constitute a defense to liability. If liability is found, the same conditions give guidance as to the remedy.

\footnotetext{
${ }^{146}$ In fact, the requirement for sharing can be counterproductive, due to "double marginalization.” Even if there is a cost-minimizing reason to supply the market with two facilities, interpreted as two firms, the sale of the input at a price higher than marginal cost will distort the market. See Stephen M. Maurer and Suzanne Scotchmer, "Profit Neutrality in Licensing: The Boundary Between Antitrust Law and Patent Law.” 2007. American Law and Economics Review 8:476-522.
} 
Of course one would want to ensure that there is no conflict between the essential facilities doctrine and other principles of antitrust law. The standard for Section 1 liability is "rule of reason" 147 which asks whether the alleged harm of the "contract in restraint of trade" outweighs the procompetitive benefits. That standard is built into the doctrine as we have formulated it above. As to Section 2 liability, Section 2 does not condemn every act that would harm competition under a "rule of reason" analysis. At the same time, any act that would be illegal under Section 2 would also satisfy Section 1's governing principle, that if the act is condemned, it is because the act harms competition. ${ }^{148}$ The Trinko Court attributes the less inclusive approach of Section 2 to the ubiquity of unilateral acts. Too broad a rule would create too great a danger of "false positives." 149

Another difference between Section 1 and Section 2 is in what it takes to trigger liability. Our analysis says nothing about whether a refusal to deal can trigger Section 2 liability without some additional act. This unresolved question only comes up under Section 2. Section 1 requires an agreement, and the agreement supplies the act.

\footnotetext{
${ }^{147}$ First articulated in Standard Oil, supra.
}

${ }^{148}$ Copperweld Corp. v. Independence Tube Corp., 467 U.S. 752 (1984) at 774. Professor Hovenkamp similarly acknowledges that the essential facilities doctrine must logically apply to both sections. Herbert Hovenkamp, Federal Antitrust Policy: The Law of Competition and Its Practice (West 2011) at 336.(“Of course, once a properly defined 'essential facility' is at issue, it really should not matter whether the facility is controlled by a single firm or a group of firms acting in concert.”)

${ }^{149} I d$. at 414. 


\section{Appendix: Cost Sharing}

In this section we evaluate the remedy of spinning off the shared facility and insisting that it be priced on cost-sharing terms. If the cost shares are fixed, then the cost sharing has no effect on prices, although it might chase small firms out of the market. To avoid this problem, the more reasonable cost sharing seems to be according to revenue shares or demand shares. We show that both schemes lead to higher prices in the market than fixed shares, and that demand-based cost sharing leads to even higher prices than revenue-based cost sharing.

Index the firms $i=1,2, . ., n$. Suppose the firms share the costs of a common facility, but set prices independently, that is, they compete on price. If the shares are fixed, for example, each firm pays $1 / n$ of the cost, then the cost shares will diminish their profit, but have no consequences for the prices they set, provided they remain in the market. The firm's best marketing strategy would be the same regardless of how much money is taken off the top to pay for the facility.

However, this will not be true if the cost shares depend on the firm's success in the market. When the prices are $\left(p_{1}, p_{2}, \ldots, p_{n}\right)$, let $D_{i}\left(p_{1}, p_{2}, \ldots, p_{n}\right)$ be the demand for firm $i$ and let $R_{i}\left(p_{1}, p_{2}, \ldots, p_{n}\right)$ be the revenue earned by firm $i$.

Then the demand share and revenue share of firm $i$ are respectively

$$
\begin{gathered}
\frac{D_{i}\left(p_{1}, p_{2}, \ldots, p_{n}\right)}{\sum_{j=1}^{n} D_{j}\left(p_{1}, p_{2}, \ldots, p_{n}\right)} \\
\frac{R_{i}\left(p_{1}, p_{2}, \ldots, p_{n}\right)}{\sum_{j=1}^{n} R_{j}\left(p_{1}, p_{2}, \ldots, p_{n}\right)}=\frac{p_{i} D_{i}\left(p_{1}, p_{2}, \ldots, p_{n}\right)}{\sum_{j=1}^{n} p_{j} D_{j}\left(p_{1}, p_{2}, \ldots, p_{n}\right)}
\end{gathered}
$$

When the (amortized) per-period cost of the facility is $K$, the profit of firm $i$ is one of the following, depending on whether the cost share is determined according to demand or revenue:

$$
\begin{aligned}
& p_{i} D_{i}\left(p_{1}, p_{2}, \ldots, p_{n}\right)-\frac{D_{i}\left(p_{1}, p_{2}, \ldots, p_{n}\right)}{\sum_{j=1}^{n} D_{j}\left(p_{1}, p_{2}, \ldots, p_{n}\right)} K \\
& p_{i} D_{i}\left(p_{1}, p_{2}, \ldots, p_{n}\right)-\frac{R_{i}\left(p_{1}, p_{2}, \ldots, p_{n}\right)}{\sum_{j=1}^{n} R_{j}\left(p_{1}, p_{2}, \ldots, p_{n}\right)} K
\end{aligned}
$$

If the cost term were replaced in either profit function with a fixed fraction $K / n$, then the most profitable choice of price, $p_{i}$, would not depend on the cost or the cost share, except that the firm might be driven out of the market. The firm would choose price to maximize revenue, 
ignoring the cost. It is because small firms might be driven out of the market that cost shares should be linked to revenues or demand.

However, we now show that if the cost share depends on relative revenues or relative sales, the sharing will affect prices, and cause prices to be higher than with fixed shares. ${ }^{150}$ Suppose, in particular, that an increase in firm i's price would decrease the revenue, $p_{i} D_{i}\left(p_{1}, p_{2}, \ldots, p_{n}\right)$. Then with fixed cost shares, the firm would not decrease the price; instead it would raise the price. However, if the costs are shared according to relative revenue, the decrease in revenue may also decrease the share of the cost that the firm pays, and will always do when total revenue (the denominator of the revenue share) decreases due to the decrease in price. This decrease in cost share might be enough so that the firm will lower the price.

Demand-based cost sharing has the same effect. A decrease in price increases the sales of firm $i$ at the expense of other vendors, thus increasing the demand-based cost share, and again diminishing the incentive to steal business by reducing price.

Moreover, the dampening of price competition is more pronounced with demand-based cost sharing than with revenue-based cost sharing, at least when the firms are symmetric and charge the same price. To see this, suppose that there is an equilibrium with revenue-based cost sharing in which all firms charge a particular price $p$. There is no loss in normalizing the equilibrium price as $p=1$. Since we contemplate a change in firm $i$ 's price, we will write the revenue share at these prices as

$$
\frac{R_{i}\left(p_{1}, p_{2}, \ldots, p_{n}\right)}{\sum_{j=1}^{n} R_{j}\left(p_{1}, p_{2}, \ldots, p_{n}\right)}=\frac{p_{i} D_{i}\left(p_{1}, p_{2}, \ldots, p_{n}\right)}{p_{i} D_{i}\left(p_{1}, p_{2}, \ldots, p_{n}\right)+\sum_{j \neq i}^{n} D_{j}\left(p_{1}, p_{2}, \ldots, p_{n}\right)}
$$

If firm $i$ reduces the price $p_{i}$ to attract more market share, so that $D_{i}\left(p_{1}, p_{2}, \ldots, p_{n}\right)$ increases, then the demand-based share $\frac{D_{i}\left(p_{1}, p_{2}, \ldots, p_{n}\right)}{\sum_{j=1}^{n} D_{j}\left(p_{1}, p_{2}, \ldots, p_{n}\right)}$ increases by more than the revenuebased share $\frac{R_{i}\left(p_{1}, p_{2}, \ldots, p_{n}\right)}{\sum_{j=1}^{n} R_{j}\left(p_{1}, p_{2}, \ldots, p_{n}\right)}$, because $D_{i}\left(p_{1}, p_{2}, \ldots, p_{n}\right)$ increases by more than $p_{i} D_{i}\left(p_{1}, p_{2}, \ldots, p_{n}\right)$. Since there is more effect on the share of cost that the firm must pay, it has even less incentive to compete by lowering price.

\footnotetext{
${ }^{150}$ This follows Yooki Park and Suzanne Scotchmer, 2005, "Digital Rights Management and the Pricing of Digital Products.” NBER working paper 11532.
} 